\title{
Lung angiotensin converting enzyme activity in rats with pulmonary hypertension
}

\author{
PM KEANE, JM KAY, KL SUYAMA, D GAUTHIER, K ANDREW
}

From the Department of Laboratory Medicine, St Joseph's Hospital and Department of Pathology, Faculty of Health Sciences, McMaster University, Hamilton, Ontario, Canada

ABSTRACT We have studied serum and lung tissue angiotensin converting enzyme (ACE) activity in female Wistar rats with pulmonary hypertension induced by two different methods. Chronic pulmonary hypertension was produced in one group of 10 rats $(\mathrm{CH})$ by confinement in a hypobaric chamber $(380 \mathrm{mmHg})$ for three weeks, and in another group of 10 rats $(\mathrm{M})$ by a single subcutaneous injection of monocrotaline $(60 \mathrm{mg} / \mathrm{kg}$ body weight). In these two groups of test rats and in $20 \mathrm{un}-$

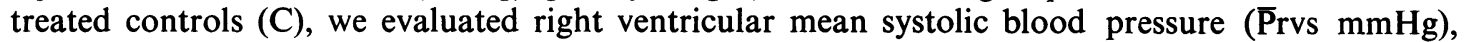
right ventricular hypertrophy, and serum $\mathrm{ACE}(\mathrm{n} \mathrm{mol} / \mathrm{ml} / \mathrm{min})$. In lung tissue homogenate, we measured the specific activity of ACE ( $\mathrm{n} \mathrm{mol} / \mathrm{mg}$ protein $/ \mathrm{min}$ ), alkaline phosphatase (AP) (IU $/ \mathrm{mg}$ protein) and lactic dehydrogenase (LDH) (IU/mg protein). The $\overline{P r v s}$ in groups $\mathrm{C}, \mathrm{CH}$, and $\mathrm{M}$ was $25 \pm 7 \mathrm{SD}, 41 \pm 7$, and $51 \pm 5$, respectively. The ratio of right to left ventricular weight $(\mathrm{RV} /$ $(\mathrm{LV}+\mathrm{S}) \%$ in groups $\mathrm{C}, \mathrm{CH}$, and $\mathrm{M}$ was $29 \pm 4,52 \pm 5$, and $56 \pm 7$, respectively. The lung tissue $\mathrm{ACE}$ in groups $\mathrm{C}, \mathrm{CH}$, and $\mathrm{M}$ was $85 \pm 11,65 \pm 20$, and $22 \pm 5$, respectively. In groups $\mathrm{CH}$, and $\mathrm{M}$ the Prvs and $\mathrm{RV} /(\mathrm{LV}+\mathrm{S}) \%$ were significantly elevated above control values while lung ACE was significantly decreased $(\mathrm{p}<0.05)$. There was a significant inverse relationship between lung ACE on one hand, and Prvs $(r=-0.73)$ and $\mathrm{RV} /(\mathrm{LV}+\mathrm{S}) \%(\mathrm{r}=-0.71)$ on the other hand. Serum ACE and lung AP were unchanged. In group $M$ there was a slight but significant reduction in lung LDH. Chronic pulmonary hypertension, irrespective of its method of production, is associated with decreased lung ACE. The reduction in lung ACE is inversely proportional to the severity of pulmonary hypertension and right ventricular hypertrophy.

Angiotensin converting enzyme (peptidyldipeptide hydrolase EC 3.4.15.1) is an exopeptidase that catalyses the hydrolytic removal of carboxy-terminal dipeptide residues from polypeptide substrates. ${ }^{1}$ Two such reactions of angiotensin converting enzyme (ACE) may participate in the regulation of blood pressure. First, it converts the inactive decapeptide angiotensin I to the potent vasoconstrictive octapeptide angiotensin II. Secondly, it inactivates the vasodilator nonapeptide bradykinin. The role of ACE and angiotensin II in the humoral control of the systemic and pulmonary circulations is not entirely clear although it has been postulated that angiotensin II is an agent necessary for the pulmonary vasoconstrictor response to alveolar hypoxia. ${ }^{2}$ $\mathrm{ACE}$ has been found in association with the microvascular beds of many tissues including the spleen,

Address for reprint requests: Dr JM Kay, Department of Laboratory Medicine, St Joseph's Hospital, Hamilton, Ontario, Canada L8N 1 Y4. pancreas, adrenal, liver, and kidney. ${ }^{3}$ However, it has been calculated that most of the ACE activity in the body occurs in the lungs ${ }^{4}$ where the enzyme has been localised on the luminal surface of pulmonary endothelial cells in relation to the plasma membrane. $^{5}$ It has been shown that the pulmonary conversion of angiotensin I to angiotensin II is a function of the vascular surface area and the transit time of blood through the lung. ${ }^{6}$ Accordingly, it might be expected that diffuse lung disease and pulmonary hypertension in particular would be associated with alterations of lung ACE activity. However, although there have been a few studies of lung ACE activity in acute hypoxia, ${ }^{7} 8$ chronic hypoxia, ${ }^{9}$ and acute lung injury, ${ }^{10} 11$ there has been only one study specifically related to pulmonary hypertension. ${ }^{12}$

The purpose of this paper is to describe the effect of pulmonary hypertension on lung ACE activity. We induced chronic pulmonary hypertension in one 
group of rats using chronic hypobaric hypoxia ${ }^{13}$ and in another group using a subcutaneous injection of the pyrrolizidine alkaloid monocrotaline. ${ }^{14}$ At the end of the experiment we evaluated pulmonary hypertension and right ventricular hypertrophy. We measured serum ACE levels and determined the specific activity of ACE, lactic dehydrogenase (LDH), and alkaline phosphatase (AP) in lung tissue homogenate.

\section{Methods}

\section{CHRONIC HYPOXIC PULMONARY} HYPERTENSION

Twenty female Wistar rats were divided into control and test groups of equal number. Their initial mean body weights were $165.0 \mathrm{~g} \pm 13.1 \mathrm{SD}$ and $166.5 \mathrm{~g}$ $\pm 10 \cdot 3$, respectively. The 10 test rats were confined in a cylindrical steel hypobaric chamber (1600 1 volume) with six glass windows which was initially decompressed to $460 \mathrm{mmHg}$. The pressure was progressively reduced in daily stages so that after one week it was $380 \mathrm{mmHg}$. The rats remained at this pressure for a further two weeks. The pressure in the hypobaric chamber was reduced by an electrically driven vacuum pump which ensured that the air was changed 12 times per hour. The relative humidity was maintained at approximately $40 \%$ by treating the air entering the chamber. The chamber was opened for about 30 minutes twice weekly to clean the cages, replenish food and water, and weigh the animals. After three weeks of chronic hypoxia, the mean right ventricular systolic blood pressure (Prvs) was measured in the control and test rats using a method previously described in detail. ${ }^{15}$ Under light ether anaesthesia the right external jugular vein was exposed and cannulated, using a modified 21-gauge disposable needle measuring 0.75 $\mathrm{mm}$ in external diameter and $3.4 \mathrm{~cm}$ in length. The tip of the cannula was guided through the right atrium and tricuspid valve into the right ventricle. The pressure was measured using a Hewlett Packard transducer $(1280 \mathrm{C})$ attached to a pressure coupler $(8805 \mathrm{C})$ and thermotip recorder (7702B). The pressure was measured in the chronically hypoxic rats from 30 to 60 minutes after removal from the hypobaric chamber. After measurement of Prvs a sample of blood was obtained through the cannula from the right ventricle. The serum was separated and stored at $-20^{\circ} \mathrm{C}$ before ACE assay using the method described below. The rats were then killed. The left lung was removed, washed in ice-cold physiological saline and stored at $-20^{\circ} \mathrm{C}$ to await ACE assay. The heart was dissected after fixation in $10 \%$ formol saline and weighed using a Sartorius semi-micro analytical balance. Right ventricular hypertrophy was evaluated by expressing the weight of the free wall of the right ventricle (RV) as a percentage of the weight of the left ventricle and interventricular septum ( $\mathrm{LV}+\mathrm{S})$ and also as a ratio of the final body weight (FBW).

\section{MONOCROTALINE PULMONARY}

HY PERTENSION

Twenty female Wistar albino rats were divided into a group of 10 control animals and 10 test animals whose respective initial mean body weights were $103.4 \mathrm{~g} \pm 7 \cdot 6$ and $101.5 \pm 4 \cdot 1$. Each test rat was given a single subcutaneous injection of a $2 \%$ aqueous solution of monocrotaline hydrochloride. The dose of monocrotaline was $60 \mathrm{mg} / \mathrm{kg}$ body weight. Three weeks later the test and control rats were anaesthetised with ether for measurement of Prrvs as described above. Blood and the left lung were taken for enzyme assay while the heart was dissected after formalin fixation in $10 \%$ formol saline for the evaluation of right ventricular hypertrophy.

Table 1 Body weights, heart weights, and right ventricular mean blood pressure in control rats and rats with pulmonary hypertension caused by chronic hypoxia and monocrotaline

\begin{tabular}{|c|c|c|c|c|}
\hline & \multicolumn{2}{|c|}{ Chronic hypoxia experiment } & \multicolumn{2}{|c|}{ Monocrotaline experiment } \\
\hline & Control & Chronic hypoxia & Control & Monocrotaline \\
\hline \multicolumn{5}{|l|}{ Initial body weight (g) } \\
\hline $\begin{array}{l}(n=10) \\
\text { Final body weight }(\mathrm{g})\end{array}$ & $165 \cdot 0 \pm 13 \cdot 1$ & $166.5 \pm 10.3$ & $103.4 \pm 7 \cdot 6$ & $101 \cdot 5 \pm 4 \cdot 1$ \\
\hline$(n=10)$ & $232 \cdot 8 \pm 15 \cdot 9$ & $203 \cdot 0 \pm 15 \cdot 7^{*}$ & $209 \cdot 0 \pm 12 \cdot 0$ & $167 \cdot 0 \pm 22 \cdot 1^{*}$ \\
\hline Right ventricular weight (mg) & & & & \\
\hline $\begin{array}{l}(n=10) \\
\text { Left ventricle }+ \text { septal weight }(\mathrm{mg})\end{array}$ & $150 \cdot 9 \pm 25 \cdot 5$ & $297 \cdot 2 \pm 60 \cdot 9^{*}$ & $124 \cdot 1 \pm 13 \cdot 3$ & $235 \cdot 1 \pm 36 \cdot 7^{*}$ \\
\hline$(n=10)$ & $494 \cdot 0 \pm 43 \cdot 2$ & $578 \cdot 6 \pm 115 \cdot 0^{*}$ & $468 \cdot 7 \pm 28 \cdot 5$ & $417 \cdot 3 \pm 41 \cdot 4^{*}$ \\
\hline $\begin{array}{l}\mathbf{R V} /(\mathrm{LV}+\mathrm{S}) \% \\
\quad(\mathrm{n}=10) \\
\mathbf{R V} / \mathrm{FBW}(\mathrm{mg} / 100 \mathrm{~g})\end{array}$ & $30 \cdot 5 \pm 4 \cdot 3$ & $51 \cdot 6 \pm 5 \cdot 2 *$ & $26 \cdot 6 \pm 2 \cdot 5$ & $56 \cdot 4 \pm 7 \cdot 2^{*}$ \\
\hline $\begin{array}{l}(\mathrm{n}=10) \\
\text { Mean RV systolic pressure }(\mathrm{mmHg})\end{array}$ & $\begin{array}{l}64 \cdot 9 \pm 10 \cdot 6 \\
22 \cdot 5 \pm 6 \cdot 8 \\
(n=10)\end{array}$ & $\begin{array}{c}145 \cdot 6 \pm \\
40.8 \pm \\
(n=10)\end{array}$ & $\begin{array}{l}59 \cdot 3 \pm 5 \cdot 2 \\
27 \cdot 2 \pm 7 \cdot 0 \\
(n=9)\end{array}$ & $\begin{array}{l}143.7 \pm 34.9^{*} \\
50.6 \pm 5.4^{*} \\
(n=6)\end{array}$ \\
\hline
\end{tabular}

Results are given as mean values $\pm \mathrm{SD} .{ }^{*}=\mathrm{p}<0.05$ control versus test values, 
Table 2 Lung weights, lung protein concentrations, serum ACE activity and lung tissue ACE, LDH, and AP activities in control rats and rats with pulmonary hypertension caused by chronic hypoxia and monocrotaline

\begin{tabular}{|c|c|c|c|c|}
\hline \multirow[b]{3}{*}{ Lung weight (g) } & \multicolumn{2}{|c|}{ Chronic hypoxia experiment } & \multicolumn{2}{|c|}{ Monocrotaline experiment } \\
\hline & Control & Chronic hypoxia & Control & Monocrotaline \\
\hline & $\underset{(\mathrm{n}=10)}{0.48} \mathbf{\pm} 0.14$ & $\underset{(\mathrm{n}=10)}{0.56}+0.09$ & $\underset{(n=10)}{0.36} \underset{0.04}{ \pm}$ & $\begin{array}{l}0.57 \\
(\mathrm{n}=7)\end{array}$ \\
\hline Lung protein & $52.4 \pm 7.4$ & $58 \cdot 3 \pm 12 \cdot 3$ & $42.6 \pm 7.8$ & $49.8 \pm 8 \cdot 0^{*}$ \\
\hline $\begin{array}{l}\text { (mg/g lung) } \\
\text { Serum ACE } \\
\text { (n mol/ml/min) }\end{array}$ & $\begin{array}{l}89 \cdot 0 \pm 15 \cdot 4 \\
(n=10)\end{array}$ & $\begin{array}{l}(n=10) \\
95 \cdot 9 \pm 15 \cdot 8 \\
(n=10)\end{array}$ & $\begin{array}{l}(\mathrm{n}=10) \\
94 \cdot 2 \pm 11 \cdot 0 \\
(\mathrm{n}=9)\end{array}$ & $\begin{array}{l}(n=7) \\
95 \cdot 9 \pm 5 \cdot 4 \\
(n=7)\end{array}$ \\
\hline $\begin{array}{l}\text { Lung ACE } \\
\text { (n mol } / \mathrm{mg} \text { protein } / \mathrm{min} \text { ) }\end{array}$ & $\begin{array}{l}85 \cdot 3 \pm 13 \cdot 7 \\
(\mathrm{n}=10)\end{array}$ & $\begin{array}{l}65 \cdot 4 \pm 19 \cdot 6^{*} \\
(\mathrm{n}=10)\end{array}$ & $\begin{array}{l}84 \cdot 3 \pm 9 \cdot 1 \\
(n=10)\end{array}$ & $\begin{array}{l}22 \cdot 3 \\
(\mathrm{n}=7)\end{array}$ \\
\hline $\begin{array}{l}\text { Lung LDH } \\
\text { (IU/mg protein) }\end{array}$ & $\begin{array}{l}0.742 \pm 0.15 \\
(\mathrm{n}=10)\end{array}$ & $\begin{array}{l}0.774 \pm 0.21 \\
(\mathrm{n}=10)\end{array}$ & $\begin{array}{l}0.766 \pm 0.12 \\
(\mathrm{n}=10)\end{array}$ & $\begin{array}{l}0.681 \pm 0.06 \\
(n=7)\end{array}$ \\
\hline $\begin{array}{l}\text { Lung AP } \\
\text { (IU/mg protein) }\end{array}$ & $\begin{array}{l}17 \cdot 3 \pm 2 \cdot 7 \\
(\mathrm{n}=10)\end{array}$ & $\begin{array}{l}19 \cdot 8 \pm 8.9 \\
(\mathrm{n}=10)\end{array}$ & $\begin{array}{l}20 \cdot 7 \pm 6 \cdot 2 \\
(\mathrm{n}=10)\end{array}$ & $\begin{array}{l}17 \cdot 6 \\
(n=7)\end{array}$ \\
\hline
\end{tabular}

Results are given as mean values $\pm \mathrm{SD} .{ }^{*}=\mathrm{p}<0.05$ control versus test values.

$\mathrm{ACE}=$ angiotensin converting enzyme $\mathbf{L D H}=$ lactic dehydrogenase; $\mathbf{A P}=$ alkaline phosphatase.

ASSAY OF ACE, LDH, AND AP

Before assay the left lung was thawed, weighed using a Sartorius semi-micro analytical balance, diced by hand, and then homogenised in a Brinkman Polytron PT $10-35$ at $4^{\circ} \mathrm{C}$ in 12 volumes of assay buffer ( $500 \mathrm{~m}$ mol potassium phosphate-750 m mol sodium chloride, pH 8.3). The homogenate was filtered through Whatman number 2 paper and the filtrate was centrifuged at $5000 \mathrm{~g}$ for 30 minutes. The protein concentration was measured 16 in the supernatant fluid which was then used for enzyme assay. ACE activity was measured by a modification ${ }^{17}$ of the spectrophotometric assay described by Cushman and Cheung. ${ }^{18}$ This method measures the rate of pro- duction of hippuric acid from hippuryl-L-histidyl-Lleucine. Optimal assay conditions were obtained by using $50 \mu \mathrm{l}$ volumes of serum and $100 \mu \mathrm{l}$ volumes of lung homogenate previously diluted with six times their volumes of distilled water. These respective aliquots of serum and diluted lung homogenate were added to $150 \mu \mathrm{l}$ of $12 \mathrm{~m}$ mol hippuryl-L-histidyl-Lleucine in assay buffer. These conditions resulted in maximal enzyme activity compatible with zero order kinetics. ${ }^{19}$ AP activity was determined directly on lung homogenate and LDH activity on homogenate diluted with 40 times its own volume of physiological saline. The assays of AP and LDH were performed on an IL Multistat III Microcentrifugal Analyser

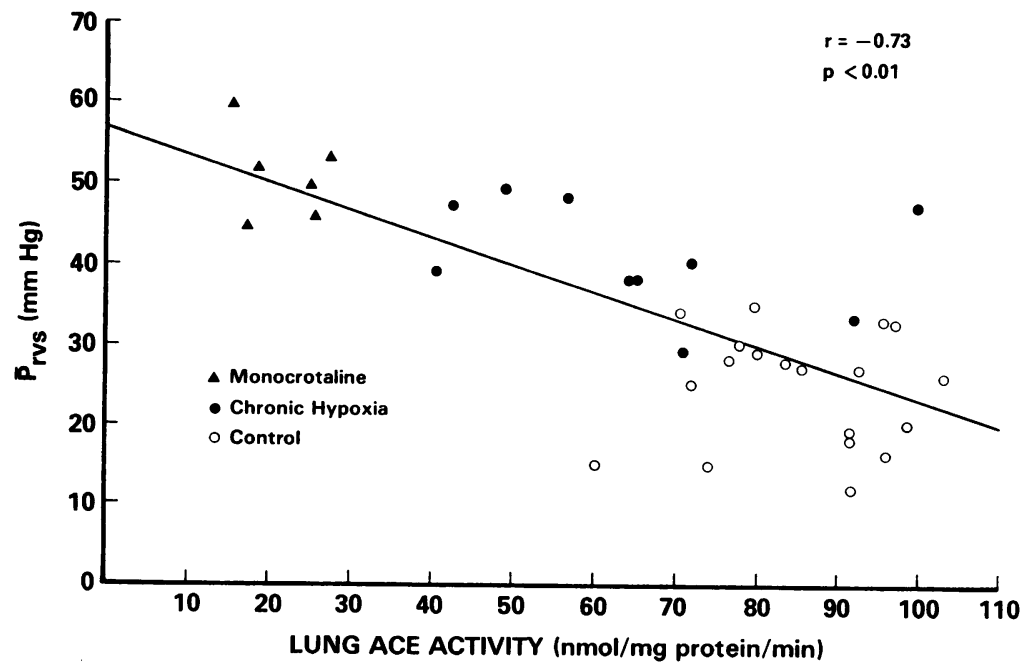

Fig 1 Relation between mean right ventricular systolic pressure (Prvs) and specific activity of pulmonary angiotensin converting enzyme $(A C E)$ in control rats and rats with pulmonary hypertension caused by either chronic hypoxia or monocrotaline. 


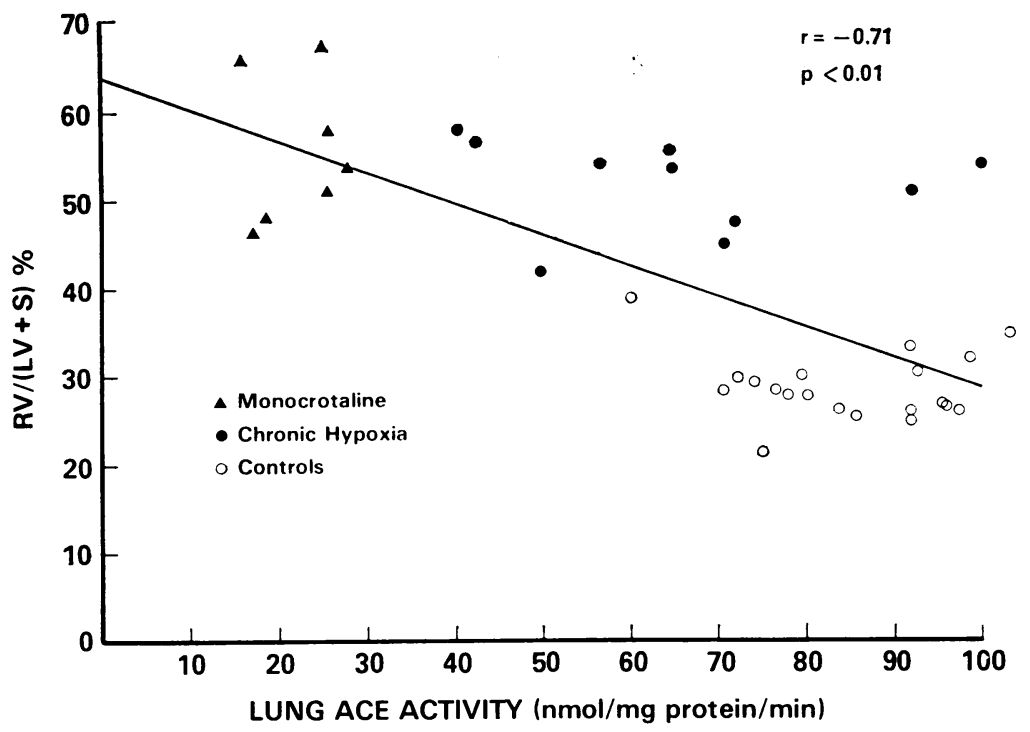

Fig 2 Relation between the ratio of right to left ventricular weight $(R V /(L V+S) \%)$ and specific activity of pulmonary angiotensin converting enzyme $(A C E)$ in control rats and rats with pulmonary hypertension caused by either chronic hypoxia or monocrotaline.

(Instrumentation Laboratory, Lexington) using kits designed for this equipment.

The animals used in this research were cared for in accordance with the regulations of the Canadian Council on Animal Care. They were allowed free access to food and water, and were subjected to an alternating sequence of 14 hours of light and 10 hours of darkness. The results of the experiments expressed as means with SD were evaluated using the $t$ test for unpaired data, and linear regression analysis. Differences in mean values were considered to be significant when $p<0.05$.

\section{Results}

In table 1 are shown the initial body weight, final body weight, cardiac ventricular weights, and Prvs in the rats exposed to chronic hypoxia and monocrotaline together with their respective controls. The rats treated with chronic hypoxia and monocrotaline developed pulmonary hypertension which was accompanied by right ventricular hypertrophy.

Table 2 records the lung weight, lung protein concentration, serum ACE activity, and the activity of ACE, LDH, and AP in lung tissue homogenate. In the rats exposed to chronic hypoxia and monocrotaline there was a significant reduction in lung $A C E$ activity which was inversely proportional to the severity of the pulmonary hypertension (fig 1) and the degree of right ventricular hypertrophy (fig 2).

\section{Discussion}

Female rats were used in this study because there is some evidence that they may be more susceptible than males to the development of hypoxic pulmonary vascular disease. ${ }^{20}$ Sex influences the chronic hepatotoxicity of pyrrolizidine alkaloids, ${ }^{21}$ but whether or not it affects the pulmonary toxicity is not known. Exposure to chronic hypobaric hypoxia ${ }^{13}$ and administration of monocrotaline ${ }^{22}$ are well known to interfere with growth. Accordingly, at the end of the experiment the rats exposed to chronic hypoxia and those given monocrotaline were significantly lighter than the respective control groups. Monocrotaline produces pulmonary oedema and exudative changes in the lung tissue. ${ }^{22}{ }^{23}$ This is probably why the lung weight and lung protein concentration were higher in the group of rats given monocrotaline when compared with the appropriate control group. The rats exposed to chronic hypoxia developed left ventricular hypertrophy. The cause of this is not clear and has been discussed in a previous paper. ${ }^{13}$ The left ventricles of the rats given monocrotaline were significantly lighter than those in the appropriate control group. This is because monocrotaline interferes with normal growth ${ }^{22}$ and the final body weight of this group of rats was significantly less than that of the controls.

We have shown that chronic pulmonary hypertension produced by two different methods is associated with decreased lung ACE activity. The lung ACE activity is inversely proportional to the severity of pulmonary hypertension and right ventricular hypertrophy. Decreased lung ACE activity in pulmonary hypertension is not part of a generalised impairment of pulmonary enzyme activity since AP and $\mathrm{LDH}$ were not similarly 
affected. ACE is bound to the cell membrane on the luminal surface of endothelial cells. ${ }^{5}$ Histochemical studies on the lung have shown that AP is associated with granular pneumocytes and non-ciliated bronchiolar epithelial cells. ${ }^{24} \mathrm{LDH}$ is associated with granular pneumocytes, macrophages, ciliated bronchiolar epithelial cells, and non-ciliated bronchiolar epithelial cells. ${ }^{24}$ In the rats treated with monocrotaline there was a slight but significant reduction in pulmonary LDH activity. The reason for this is not clear. Monocrotaline intoxication leads to a proliferation of granular pneumocytes and bronchiolar epithelium..$^{22} 23$ Accordingly, we might have expected the LDH activity to be increased rather than decreased. In a previous study we showed that chronic hypoxia did not impair the activity of pulmonary histidine decarboxylase in rats. ${ }^{26}$

Our results with chronic hypoxia are different from those of Molteni and co-workers who showed elevation of serum and lung ACE activity during the second week of exposure of mice to chronic hypobaric hypoxia. ${ }^{9}$ However, these workers measured ACE activity in acetone extracts of lung tissue. This method of tissue preparation may lead to results not strictly comparable to values expressed in specific activity terms. Furthermore, a species difference in the response of ACE to chronic hypoxia cannot be excluded. The mean serum ACE in our chronically hypoxic rats was increased but this increase was not statistically significant. The findings of Molteni and co-workers are at variance with the results of Leuenberger ${ }^{7}$ and Szidon ${ }^{8}$ who with their respective co-workers have shown that acute hypoxia in dogs leads to a rapid decrease in the lung ACE activity which is equally rapidly reversed on resumption of normoxic conditions. Hypoxia has also been shown to inhibit ACE activity in cultured endothelial cells. ${ }^{27}$

The mechanism whereby alveolar hypoxia causes pulmonary vasoconstriction is unknown. It has been suggested that angiotensin II is a humoral agent necessary for the pulmonary vasoconstrictor response to acute hypoxia ${ }^{2}$ and that the same agent is also necessary for the development of the pulmonary vascular lesions and right ventricular hypertrophy in chronic alveolar hypoxia. ${ }^{28}$ Our results showing that chronic hypoxia decreases lung ACE activity and the results of others showing that acute hypoxia decreases lung ACE activity would not support this hypothesis. Decreased ACE activity would tend to reduce rather than increase the amount of angiotensin II within the pulmonary circulation. Furthermore, experiments using the analogue octapeptide saralasin which acts as a competitive inhibitor of angiotensin II and abolishes all its cardiovascular effects do not support this hypothesis. ${ }^{29}$ The mechanism whereby monocrotaline induces pulmonary hypertension is not known although various factors have been reviewed.1430 The reduced lung ACE activity in our rats given monocrotaline is unlikely to have been caused by hypoxia. We did not measure systemic arterial oxygen tensions but this was done by Meyrick and her co-workers who found no evidence of systemic arterial hypoxemia. ${ }^{31}$ Huxtable and his co-workers placed monocrotaline in the drinking water of rats at a concentration of $20 \mathrm{mg} / \mathrm{l}$ for three weeks. ${ }^{12}$ Their animals developed right ventricular hypertrophy. They measured lung ACE activity by perfusing the lung and studying the rate of metabolism of hippuryl-histidyl-leucine. When the rate of metabolism was expressed per dry weight of lung tissue there was apparently a significant decrease in lung ACE activity. However, when the metabolism was expressed as rate per lung then there was no significant reduction. Accordingly, these workers concluded that monocrotaline administration did not impair the activity of ACE in the lung.

There are several possible mechanisms which have to be considered to explain the reduction of lung ACE activity in pulmonary hypertension. However, studies of the effect of acute hypoxia on lung ACE activity in intact dogs 78 and in cultured endothelial cells ${ }^{27}$ have suggested that decreased enzyme activity is an effect of hypoxia on the endothelial cells rather than on the enzyme per se. ACE is located on the luminal surface of pulmonary endothelial cells particularly in relation to flask-shaped indentations called caveolae intracellulares. ${ }^{5}$ The caveolae represent a specialised adaptation of the pulmonary endothelial surface which greatly increases the amount of ACE in contact with the blood. It has been suggested that during acute hypoxia a reduction in the size or number of the caveolae may occur.? This would decrease the surface area and permit streaming of substrate past the enzyme. The rapid reversibility of the reduced ACE activity during acute hypoxia excludes the possibility of profound structural changes in the endothelial cells. It is interesting that fetal rabbits ${ }^{32}$ and rats $^{33}$ which are in a state of physiological pulmonary hypertension have a much lower pulmonary ACE activity than adult animals. Soon after birth, the pulmonary ACE activity greatly increases. ${ }^{32} 33$ The reduction in lung ACE activity in pulmonary hypertension may be a protective mechanism designed to limit the elevation of the pulmonary arterial pressure. Decreased enzyme activity would lead to a reduction in the amount of the vasoconstrictor agent angiotensin II and an increase in the amount of the vasodilator substance bradykinin. In a recent study, rats with spontaneous systemic hypertension were found to have reduced ACE activity in the serum, kidney, and 
anterior pituitary when compared with normotensive controls. ${ }^{34}$ There was no reduction in ACE activity in lung, testis, epididymis, posterior pituitary, and hypothalamus. It was concluded that regulation of ACE activity may occur independently in different organs. Perhaps this regulation is brought about by morphological changes in the endothelial surface in response to alterations in intravascular pressure.

In 1976 Oparil and her co-workers studied serum ACE activity in patients with sarcoidosis, chronic obstructive pulmonary disease, and shock lung. ${ }^{35}$ Patients with sarcoidosis had increased ACE activity while those with chronic obstructive pulmonary disease and shock lung had decreased activity in the plasma. They suggested that plasma ACE activity may be a reflection of pulmonary conversion and that it can be altered by pulmonary disease. Our results do not support the idea that serum ACE activity is a reflection of pulmonary ACE activity. Our rats with pulmonary hypertension and decreased lung ACE activity had normal levels in the serum. It has been shown that in experimental acute lung injury caused by thiourea ${ }^{10}$ and paraquat ${ }^{11}$ there is an elevation of serum ACE activity which corresponds to a reduction in lung ACE activity. However, these changes are transient and last between one and two hours. Normal levels of activity return 24 hours later. Presumably acute injury to the pulmonary capillary endothelial cells causes ACE to be released from the lung into the serum. Accordingly it would seem that caution should be exercised in attempting to relate changes in serum ACE to those in the lung.

This work was supported by research grants from St Joseph's Hospital Foundation and the Medical Research Council of Canada.

\section{References}

${ }^{1}$ Erdos EG. Angiotensin I converting enzyme. Circ Res 1975;36:247-55.

2 Berkov S. Hypoxic pulmonary vasoconstriction in the rat; the necessary role of angiotensin II. Circ Res 1974;35: 256-61.

${ }^{3}$ Caldwell PRB, Seegal BC, Hsu KC. Angiotensin-converting enzyme: vascular endothelial localization. Science 1976;191:1050-1.

4 $\mathrm{Ng} \mathrm{KKF}$, Vane JR. Conversion of angiotensin I to angiotensin II. Nature 1967;216:762-6.

${ }^{5}$ Ryan JW, Ryan US, Schultz DR, Whitaker C, Chung A. Subcellular localization of pulmonary angiotensinconverting enzyme (kininase II). Biochem J 1975;146: 497-9.

${ }^{6}$ Fanburg BL, Glazier JB. Conversion of angiotensin I to angiotensin II in the isolated perfused dog lung. $J$ Appl Physiol 1973;35:325-31.

${ }^{7}$ Leuenberger PJ, Stalcup SA, Mellins RB, Greenbaum LM, Turino GM. Decrease in angiotensin $I$ conversion by acute hypoxia in dogs. Proc Soc Exp Biol Med 1978;158: 586-9.

${ }^{8}$ Szidon P, Bairey N, Oparil S. Effect of acute hypoxia on the pulmonary conversion of angiotensin I to angiotensin Il in dogs. Circ Res 1980;46:221-6.

${ }^{9}$ Molteni A, Zakheim RM, Mullis KB, Mattioli L. The effect of chronic alveolar hypoxia on lung and serum angiotensin I converting enzyme activity. Proc Soc Exp Biol Med 1974;147:263-5.

${ }^{10}$ Hollinger MA, Giri SN, Patwell S, Zuckerman JE, Gorin A, Parsons G. Effect of acute lung injury on angiotensin converting enzyme in serum, lung lavage, and effusate. Am Rev Respir Dis 1980;121:373-6.

${ }^{11}$ Hollinger MA, Patwell S, Zuckerman JE, Gorin AB, Parsons G, Giri SN. Effect of paraquat on serum angiotensin converting enzyme. Am Rev Respir Dis $1980 ; 121: 795-8$.

12 Huxtable R, Ciaramitaro D, Eisenstein D. The effect of a pyrrolizidine alkaloid, monocrotaline, and a pyrrole, dehydroretronecine, on the biochemical functions of the pulmonary endothelium. Mol Pharmacol 1978;14:1189203.

${ }^{13}$ Kay JM. Effect of intermittent normoxia on chronic hypoxic pulmonary hypertension, right ventricular hypertrophy, and polycythemia in rats. Am Rev Respir Dis 1980;121:993-1001.

${ }^{14}$ Kay JM, Smith P, Heath D, Will JA. Effects of phenobarbitone, cinnarizine, and zoxazolamine on the development of right ventricular hypertrophy and hypertensive pulmonary vascular disease in rats treated with monocrotaline. Cardiovasc Res 1976;10:200-5.

${ }^{15}$ Kay JM, Heath D. Crotalaria spectabilis: the pulmonary hypertension plant. Springfield, Illinois: Charles C Thomas, 1969:99-110.

${ }^{16}$ Meijers CA, Rutten JCJM. A simple rapid method for the determination of total nitrogen in urine. Clin Chim Acta 1969;24:308-10.

${ }^{17}$ Le Treut A, Couliou H, Delbary M, Larzul J-J, De Labarthe B, Le Gall J-Y. Le dosage de l'enzyme de conversion de l'angiotensin I par méthode spectrophotométrique. Clin Chim Acta 1979;98:1-4.

${ }^{18}$ Cushman DW, Cheung HS. Spectrophotometric assay and properties of the angiotensin-converting enzyme of rabbit lung. Biochem Pharmacol 1971;20:1637-48.

19 Lieberman J. Elevation of serum angiotensin-convertingenzyme (ACE) level in sarcoidosis. Am J Med 1975;59: 365-72.

${ }^{20}$ Smith $\mathrm{P}$, Moosavi H, Winson $\mathrm{M}$, Heath $\mathrm{D}$. The influence of age and sex on the response of the right ventricle, pulmonary vasculature and carotid bodies to hypoxia in rats. J Pathol 1974;112:11-18.

21 Jago MV. Factors affecting the chronic hepatotoxicity of pyrrolizidine alkaloids. $J$ Pathol $1971 ; 105: 1-11$.

22 Kay JM, Heath D. Observations on the heart weight and pulmonary arteries of rats fed on Crotalaria spectabilis seeds. J Pathol Bacteriol 1966;92:385-94.

${ }^{23}$ Kay JM, Gillund TD, Heath D. Mast cells in the lungs of rats fed on Crotalaria spectabilis seeds. Am J Pathol $1967 ; 51: 1031-43$

24 Etherton JE, Conning DM. Enzyme histochemistry of the lung. In: Bakhle YS, Vane JR, eds. Metabolic functions of the lung. New York: Marcel Dekker, 1977:233-58.

${ }^{25}$ Kay JM, Smith P, Heath D. Electron microscopy of Crotalaria pulmonary hypertension. Thorax 1969;24: 511-26.

${ }^{26}$ Kay JM, Waymire JC, Grover RF. Lung mast cell hyperplasia and pulmonary histamine-forming capacity in hypoxic rats. Am J Physiol 1974;226:178-84.

${ }^{27}$ Stalcup SA, Lipset JS, Woan J-M, Leuenberger P, Mellins RB. Inhibition of angiotensin converting enzyme activity 
in cultured endothelial cells by hypoxia. J Clin Invest 1979;63:966-76.

${ }^{28}$ Zakheim RM, Mattioli L, Molteni A, Mullis KB, Bartley J. Prevention of pulmonary vascular changes of chronic alveolar hypoxia by inhibition of angiotensin I-converting enzyme in the rat. Lab Invest 1975;33:57-61.

${ }^{29}$ Hales CA, Rouse ET, Kazemi H. Failure of saralasin acetate, a competitive inhibitor of angiotensin II to diminish alveolar hypoxic vasoconstriction in the dog. Cardiovasc Res 1977;11:541-6.

${ }^{30}$ Heath D, Kay JM. Diet, drugs, and pulmonary hypertension. In: Yu PN, Goodwin JF, eds. Progress in cardiology. Philadelphia: Lea and Febiger, 1978;7: 125-40.

${ }^{31}$ Meyrick B, Gamble W, Reid L. Development of Crotalaria pulmonary hypertension: hemodynamic and structural study. Am J Physiol 1980;239:H692-702.

${ }^{32}$ Stalcup SA, Pang LM, Lipset JS, Odya CE, Goodfriend TL, Mellins RB. Gestational changes in pulmonary converting enzyme activity in the fetal rabbit. Circ Res 1978;43:705-11.

${ }^{33}$ Wallace KB, Bailie MD, Hook JB. Development of angiotensin-converting enzyme in fetal rat lungs. $A m J$ Physiol 1979;236:R57-60.

${ }^{34}$ Polsky-Cynkin R, Reichlin S, Fanburg BL. Angiotensin-Iconverting enzyme activity in the spontaneously hypertensive rat. Proc Soc Exp Biol Med 1980;164:242-7.

${ }^{35}$ Oparil S, Low J, Koerner TJ. Altered angiotensin I conversion in pulmonary disease. Clin Sci Mol Med 1976; 51 : $537-43$ 